\title{
An Overview of the Downdraft Rice Husk Gasifier Technology for Thermal and Power Applications
}

\author{
Alexis T. Belonio ${ }^{1, *}$, Joel A. Ramos ${ }^{2}$, Manuel Jose C. Regalado ${ }^{3}$ and Victoriano B. Ocon ${ }^{4}$ \\ ${ }^{1}$ Senior Research Fellow, ${ }^{2}$ Science Research Specialist, and ${ }^{3}$ Deputy Executive Director for Research, \\ Philippine Rice Research Institute, Science City of Munoz, Nueva Ecija, Philippines; ${ }^{4}$ CEO, Suki Trading \\ Corporation, Lapu-Lapu City, Cebu, Philippines
}

\begin{abstract}
An overview of the downdraft rice husk gasifier (DDRHG) for thermal and power applications is herein presented. The different designs of the downdraft rice husk gasifier with reactor diameter ranging from 0.10 meter to 1.20 meter are discussed in detail. Smaller units of the DDRHG were found to have performed well in fixed bed. Larger units of the gasifier, on the other hand, are suited for moving-bed type making possible continuous operation without discharging and recharging the reactor. Present thermal applications of the gasifier includes: domestic cookstove, bakery oven, dryers, rotary kiln, steam boiler, and torrefyer. The DDRHG is also used to run surplus gasoline engines for driving water pump, micro-mill, and electric generator without any modification. The advantages and limitations of the gasifier as well as its environmental and socio-economic benefits over the use of conventional fossil-fueled systems are enumerated.

At present, the investment cost for the gasifier ranges from PHP2,000 to 2,500.00 (USD $1=$ PHP40.00) per kWt for thermal application and PHP20,000.00 to 30,000 per kWe for power generation. The cost of using the gasifier is much cheaper than that of the conventional fossil fuel and the investment can be recovered in a shorter period.
\end{abstract}

Keywords: Downdraft, Gasifier, Rice Husks, Heat and Power.

\section{INTRODUCTION}

Alternative sources of energy have been the main agenda of many development groups in the power sector not only in the Philippines but also in countries across the globe, especially those that are highly dependent on crude oil as fuel. Agriculture, which is one of the basic industries in the Philippines, is greatly affected by the continuous price fluctuation of fossil fuel. Failure to address the issue on the supply of a low cost fuel, the aim of the agriculture sector to intensify mechanization in the country cannot be achieved.

Rice husk is an abundant biomass resource in the Philippines, in Asia and in other rice-producing countries. Annually, at least 2 million metric tons of rice husks is produced throughout the different regions in the country [1, 2]. A kilo of rice husk contains around $3,000 \mathrm{kcal}$ of heat and a high percentage of ash about $20 \%$ [3]. However, utilization of rice husks for both thermal and power applications is hindered by the following: (a) high $\mathrm{CO}_{2}$ and black carbon emissions; (b) low heat transmission efficiency; (c) high cost and power requirement; and (d) difficulty of handling rice husks as fuel for the conventional direct combustion furnaces. These concerns are eliminated in gasification process. Converting rice husks to gas through gasification is one of the practical approaches in

*Address correspondence to this author at the Senior Research Fellow, Philippine Rice Research Institute, Science City of Munoz, Nueva Ecija, Philippines; Tel: +63 (44)456-0394 loc 308; Fax: +63 (44)456-0258 loc 311; E-mail: atbelonio@yahoo.com achieving a clean and low-cost form of energy from agri-residues [1, 2, 4, 5]. To date, there are different types of gasifiers that can convert rice husk into flammable gas, however, the downdraft-type was found effective for rice husks as feedstock for the following reasons: (a) it has low tar and smoke emission; (b) it can operate either in batch or in continuous mode; (c) it requires low investment; and (d) it has low operating cost per power output [2, 6, 7].

The development of DDRHG in the Philippines has started way back in early 80's when the DA-IRRI Program for Small Farm Equipment designed a system that supplied heat to a rotary flash paddy dryer [1]. This move was followed by other government institutions like the Department of Science and Technology that developed a batch-type rice husk gasifier for firing brick kiln, in 1990's. In the early 2000's, further development on the downdraft-type rice husk gasifier was simultaneously carried out at the Department of Agricultural Engineering and Environmental Management of the Central Philippine University and at the Rice Engineering and Mechanization Division of the Philippine Rice Research Institute [1, 2, 8, 9]. Batchand continuous-type rice husk gasifiers, with reactor diameter ranging from 0.10 to $1.2 \mathrm{~m}$, were developed for thermal and power applications. Presently, the technology has gone its way to commercialization meeting the need of various industries. Cooperating fabricators were tapped in the production of the DDRHG, but on a limited scale. 
This paper gives an overview of the DDRHG developed in the Philippines for thermal and power applications.

\section{THE DDRHG}

The DDRHG converts rice husk fuel into gas by burning it inside the reactor with limited amount of air. The combustion air is usually limited to 0.3 or 0.4 of the stoichiometric air, which is $4.7 \mathrm{~kg}$ air per $\mathrm{kg}$ of fuel. This is about 1.28 to $1.50 \mathrm{~m}^{3}$ of air per $\mathrm{kg}$ of fuel [2, 10, 11]. The air used in burning rice husks moves in an opposite direction with the moving fire zone layer. As the air passes through the burning layer of rice husks, gas is produced through the series of thermo-chemical reactions with the carbon present in the burning rice husks. The combustible gas produced is rich in carbon monoxide $(\mathrm{CO})$, hydrogen $\left(\mathrm{H}_{2}\right)$ and a little of methane $\left(\mathrm{CH}_{4}\right)$. The gas is known as "producer gas," which has low calorific value of about $1,200 \mathrm{kcal} / \mathrm{m}^{3}$ [10]. With proper mixture of air, the producer gas can be directly burned in a gas burner to produce heat or it can be used as an alternative fuel for a gasoline engine or as a supplement fuel for diesel engine [10, 11].

\subsection{Principle of Gasifying Rice Husks}

There are four distinct zones that occur when gasifying rice husks, as shown in Figure 1. These are as follows: (a) drying, (b) pyrolysis, (c) gasification, and (d) combustion zones. The drying zone occurs as soon as the air is introduced into the bed of fuel. Organic acids and other liquids are released in this zone. Next to drying zone is the pyrolysis zone, which is where rice husks reach a temperature of about $200^{\circ}$ until $500^{\circ} \mathrm{C}$. In here, large amount of tar and gases, containing carbon dioxide including other chemical liquids, are released. A small amount of gas is produced in this zone. In the gasification or reduction zone, the partial burning of rice husks produces $\mathrm{CO}, \mathrm{H}_{2}, \mathrm{CH}_{4}$, and other non-combustible gases such as nitrogen. The temperature in this zone ranges from $500^{\circ}$ to $800^{\circ} \mathrm{C}$ or even higher, depending on the amount of air supplied to the fuel bed. It is in this zone where thermo-chemical reaction takes place in which the water and the hydrogen gas obtained in pyrolysis react with the carbon, carbon monoxide, and carbon dioxide gases producing more amount of carbon monoxide as well as hydrogen gases. In the combustion or oxidation zone, the carbon in the char is further burned producing carbon dioxide and releasing heat. The amount of char produced from the gasifier is about 30 to $35 \%$ of the rice husks input. The char is a good material for agriculture.

The percentage composition of various gases [10], with varying moisture content and equivalence ratio of rice husks, are given in Tables $\mathbf{1}$ and $\mathbf{2}$.

\subsection{Classification of DDRHG}

DDRHG, as shown in Figure 2, are generally classified into: (a) Fixed-bed and (2) Moving-bed. In fixed- bed gasifier, rice husks are not moved throughout the process; whereas in moving- bed, rice husks are allowed to move downward as they undergo gasification. By allowing rice husks to move, a continuous operation in producing gas is obtained. The fixed-bed gasifier is more appropriate for batch mode while the moving-bed is best suited for continuous mode of operation. Moreover, fixed-bed can be made to operate on a semi-continuous mode by providing the system dual reactor. Ignition of rice husk fuel can be done either from the top or from the bottom, depending on the design of the reactor.

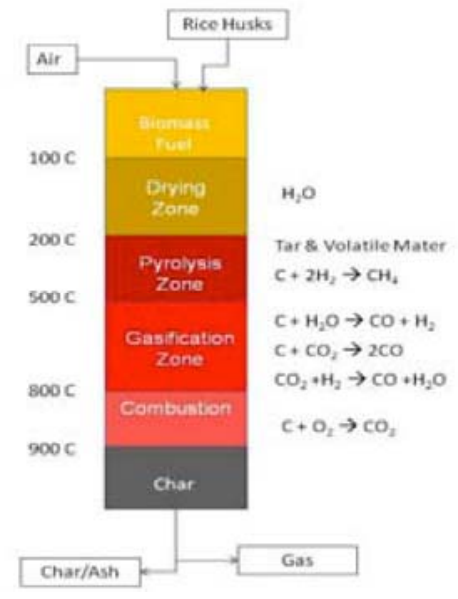

Figure 1: The Process Zones in Rice Husk Gasifier Bed.
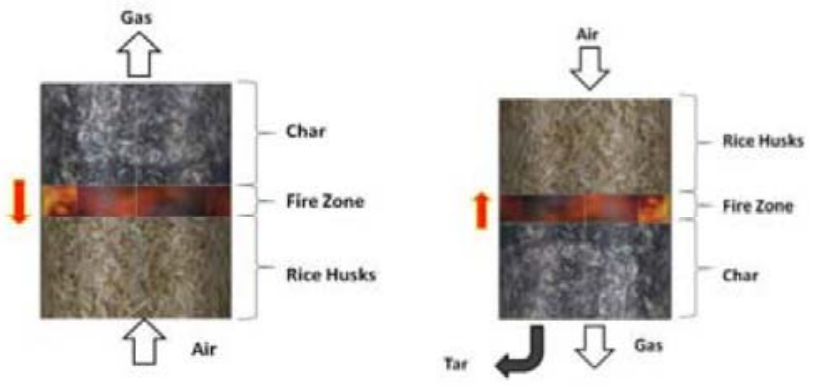
Table 1: Percentage Composition of Gases from Rice Husks at Varying Moisture Content

\begin{tabular}{|c|c|c|c|c|}
\hline \multirow{2}{*}{ Gas } & \multicolumn{5}{|c|}{ Moisture Content } \\
\cline { 2 - 5 } & $\mathbf{1 0 \%}$ & $\mathbf{2 0 \%}$ & $\mathbf{3 0 \%}$ & $\mathbf{4 0 \%}$ \\
\hline \hline $\mathrm{CO}$ & 26.1 & 22.3 & 18.6 & 21.5 \\
\hline $\mathrm{H}_{2}$ & 20.6 & 21.2 & 0 & 0 \\
\hline $\mathrm{CH}_{4}$ & 0 & 0 & 9.5 & 10.3 \\
\hline $\mathrm{CO}_{2}$ & 6.6 & 8.2 & 18.0 & 24.0 \\
\hline $\mathrm{H}_{2} \mathrm{O}$ & 8.6 & 12.8 & & \\
\hline
\end{tabular}

At $\mathrm{T}=1000^{\circ} \mathrm{C}$ and $\Phi 0.3$.

Source: [10].

Table 2: Percentage Composition of Gases from Rice Husks at Varying Equivalence Ratio

\begin{tabular}{|c|c|c|c|c|}
\hline \multirow{2}{*}{ Gas } & \multicolumn{5}{|c|}{ Equivalence Ratio } \\
\cline { 2 - 5 } & $\mathbf{0 . 3}$ & $\mathbf{0 . 4}$ & $\mathbf{0 . 5}$ & $\mathbf{0 . 6}$ \\
\hline \hline $\mathrm{CO}$ & 18.6 & 14.7 & 11.4 & 8.6 \\
\hline $\mathrm{H}_{2}$ & 21.5 & 16.3 & 0 & 0 \\
\hline $\mathrm{CH}_{4}$ & 0 & 0 & 11.7 & 12.6 \\
\hline $\mathrm{CO}_{2}$ & 9.5 & 10.6 & 20.4 & 21.1 \\
\hline $\mathrm{H}_{2} \mathrm{O}$ & 18.0 & 19.4 & & 0 \\
\hline
\end{tabular}

At $\mathrm{T}=1000^{\circ} \mathrm{C}$ and $\mathrm{MC} 30 \%$ wet basis.

Source: [10].
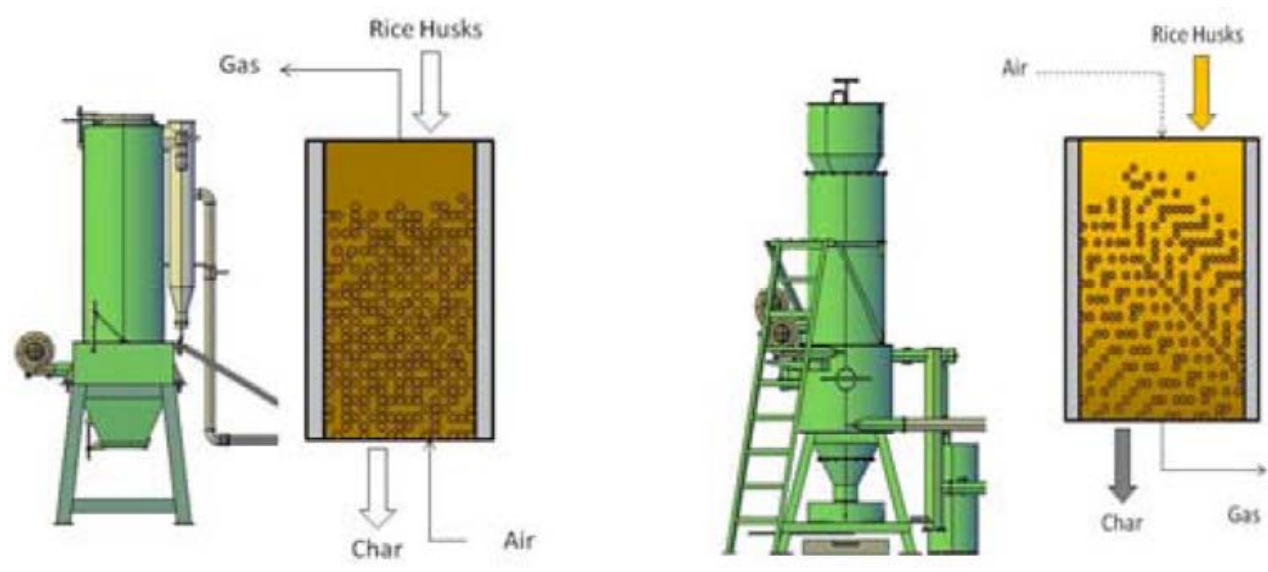

Figure 2: The Two General Classifications of DDRHG.

\subsection{Design}

The DDRHG has several designs and sizes, as shown in Figure 3, depending on the intended application and on the energy demanded from the system. The size varies from 0.1 meter, for a smalldiameter domestic stove, to 1.2 meter, for large-scale thermal and power applications. The specific gasification rate used in the design ranges from 80 to $200 \mathrm{~kg} / \mathrm{hr}-\mathrm{m}^{2}$, depending on the size of the reactor. For fixed-bed type, the height of the reactor affects the operating time of the gasifier. The higher the reactor, the longer is the operating time. For moving-bed type, on the other hand, the height of the reactor does not affect the operating time of the gasifier. A moving-bed gasifier not only has a longer operating time than fixedbed but also it can be operated continuously, as needed. Moreover, the power output of the gasifier is a function of the reactor diameter and of the amount of air used in gasifying the fuel. Doubling the diameter of the reactor increases the power output by four times.

A gas burner is provided for the system when the gasifier is intended for heating application; while, a gas 

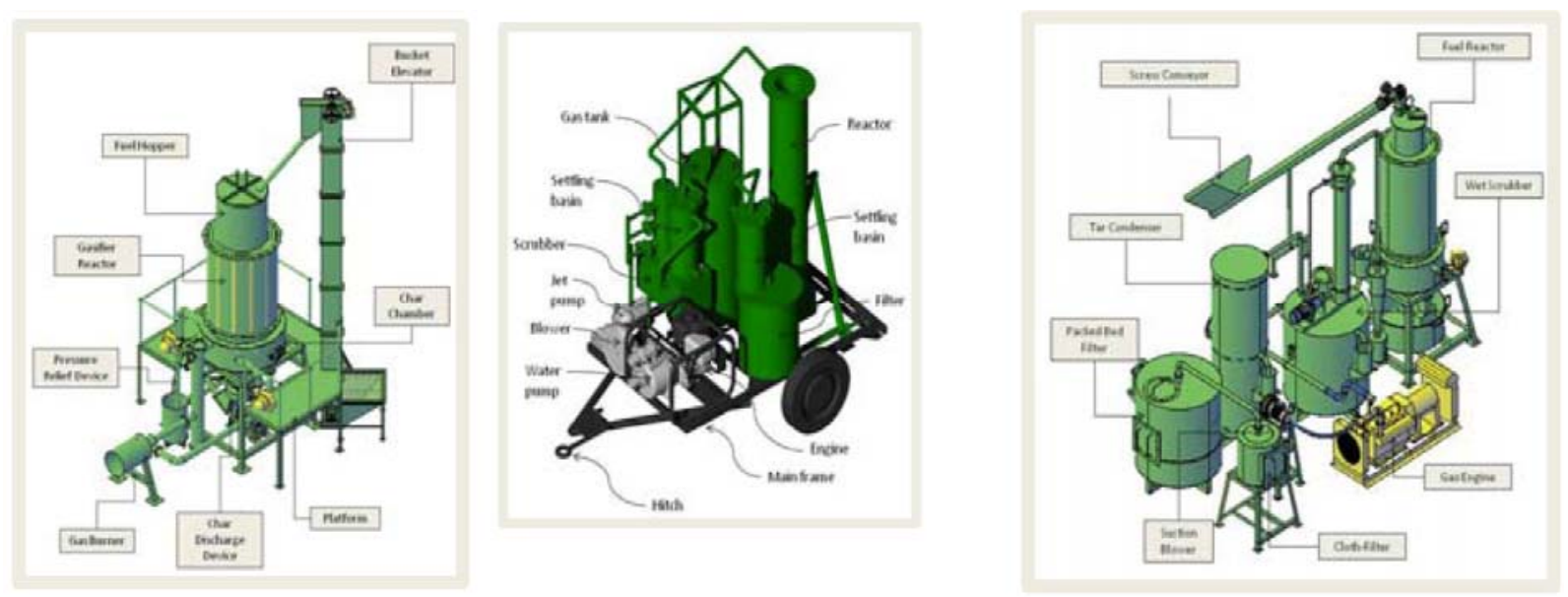

Figure 3: The Different Designs of DDRHG for Thermal and Power Applications.

conditioning unit is incorporated in the system when the gasifier is intended for generating power. Small gasifier units are provided with trailers to facilitate transfer from one place to another for mobile operation; whereas, large units are made modular for ease of fabrication and installation.

\section{PRESENT APPLICATIONS OF THE GASIFIER}

At present, DDRHG are used for diverse applications. Table 3 shows the various applications of the DDRHG with the given reactor diameter and the type or classification of the gasifier unit.

\subsection{Domestic Cooking}

The gasifier for domestic application (Appendix 1) has $10-\mathrm{cm}$ up to $16-\mathrm{cm}$ diameter reactor, which provides an average power output of $1 \mathrm{kWt}$. Most of the designs of the gasifier for this application are batchtype operating on a top-lit mode with the burner directly sat on top of the reactor. The height of the reactor varies from $40 \mathrm{~cm}$ to $80 \mathrm{~cm}$ giving 20 to 40 minutes operating time, enough to cook one to two meals per load of fuel. Recently, a continuous-type gasifier was developed with the burner, either single or double, stood separately from the reactor. For batch-type gasifier, ignition of fuel is from the top. For continuoustype, on the other hand, ignition of fuel is from the bottom. The gas generated in the reactor is channeled to the burner(s) through a pipe. The size of the fan used for domestic gasifier stoves varies from 3- to 16watt operating either on a 12 -volt DC or on a 220 -volt AC power source. A dimmer switch is used with $A C$ fan to control the airflow. With DC fan, the amount of air supplied to the rice husk fuel is controlled by regulating the voltage input of the fan. In some cases, the

Table 3: Reactor Sizes, Classifications, and Applications of DDRHG

\begin{tabular}{|c|c|c|}
\hline Reactor Size $\mathbf{( c m})$ & Classification & Application \\
\hline \hline 10 & Fixed- and Moving-Bed & Domestic Cooking \\
\hline 14 & Fixed- and Moving-Bed & Domestic Cooking \\
\hline 15 & Fixed-Bed & Water Pumping \\
\hline 16 & Moving-Bed & Domestic Cooking \\
\hline 25 & Fixed-Bed & Wakery oven \\
\hline 30 & Moving-Bed & Cottage Industry/ Bakery Oven \\
\hline 35 & Moving-Bed & Drying (Grain and Shredded Plastics) \\
\hline 40 & Moving-Bed & Drying/ Electric Generation \\
\hline 60 & Moving-Bed & Steam Boiler/ Rotary Kiln \\
\hline 80 & Moving-Bed & Rubber Baking \\
\hline 100 & Moving-Bed & Power Generation/ Torrefaction \\
\hline 120 & Moving-Bed &
\end{tabular}


intensity of the flame can be controlled by adjusting the fan opening. For multiple-burner gasifier stoves, however, ball valves are often used to control the amount of gas. So far, the stove is globally disseminated, particularly in Asia, Africa, and South America. Different versions of the stove already appeared in the market, addressing specific requirement of the respective target users.

\subsection{Cottage Industry Cooking and Heating}

The gasifiers for this application are a bit larger compared with those used for domestic cooking. They operate on a continuous mode since the cooking or heating requirement of catering services, restaurants, and candy makers is much longer. These gasifiers have a slightly larger reactor diameter ranging from 0.2 meter to 0.4 meter, giving a power output of around 10 to $40 \mathrm{kWt}$. The number of burner varies from 2 to 8 burners, depending on the size of the reactor. Lately, a 0.35-meter diameter reactor with two burners (Appendix 1) was developed for cocosugar production. This two-burner stove can boil two 14 liters of water within 15 minutes or 20 liters of water within 30 minutes, with $12 \mathrm{~kg}$ of rice husk consumption per hour. Using a $2 \frac{1}{2}$-in. electric blower, gas is generated in the reactor within 10 to 15 minutes from the time the fuel was ignited. Three to four units of this type of gasifier can be operated and maintained by one person at a time. The main advantage of this system over the traditional direct combustion system used for industry cooking or heating is that heat is uniformly maintained since the amount of gas burned in the burner can be regulated.

\subsection{Bakery Oven}

The gasifier for this application was initially designed with 0.25-meter diameter dual-reactor, which was adopted for the two units of 12-plate, two-deck LPG-fired oven on hand. It is a batch type so it has a relatively shorter start-up time (i.e., 2 minutes) to generate combustible gases. A larger size of the same gasifier model was also built for medium-sized bakery shops in Panay Island which gave the bakery shops significant amount of saving over the use of LPG-fueled oven. In this model, the height of the reactor was doubled to prolong the operation time. Recent development on this application by the CLSU-CRHET Rice Husk Project using a continuous-type reactor (Appendix 2), which was used with an 8-plate bakery oven, has shown that a 0.3-meter diameter reactor can bake "pandesal" at a temperature of $140^{\circ}$ to $160^{\circ} \mathrm{C}$ within 20 minutes. The rice husk consumption is between 7 to 8 sacks per hour. No smoke was observed inside the oven. During the early development of DDRHG, a larger version of the gasifier having a diameter of 1.0 meters was built for baking rubber. This gasifier operates on a semi-continuous mode and produces baked rubber with better quality (purer) as compared with those baked using conventional fuel.

\subsection{Drying}

In this application, the gasifier is used to supply heat to a conventional grain dryer. Since drying requires longer operation, gasifiers for this application are designed to operate in a continuous mode. The 0.4meter diameter reactor gasifier was found adequate in supplying the heat requirement for drying 4.5 tons of paddy; whereas, the 0.6-meter diameter reactor gasifier (Appendix 3) was found sufficient for drying 6 tons of paddy per load. A drying temperature of $45^{\circ}$ to $55^{\circ} \mathrm{C}$ was achieved using the DDRHG. It was also observed that using the gasifier no odor of burnt rice husks was imparted to the paddy being dried. The main advantage of this technology over the use of other system available in the market is that it works well for seed drying since the drying temperature can be easily controlled, with very minimal fluctuation. At present, a 0.6-meter diameter reactor gasifier was recently tested at the Philippine Rice Research Institute (PHILRICE) to supply heat to a 6-ton capacity re-circulating paddy dryer. Results have shown that the gasifier is sufficiently able to meet the temperature and operational requirements of the dryer.

\subsection{Rotary Kiln and Torrefyer}

The gasifier is used to supply heat for firing a rotary kiln and for torrefying biomass. For rotary kiln (Appendix 4), the burning gas is directed to the rotating chamber to raise the temperature of the product and subsequently bring its moisture down to zero level. For torrefyer (Appendix 5), the burning gas is also directed to the rotating chamber but to burn the product in order to remove volatile matters. The gasifier used for rotary kiln has 0.6-meter diameter reactor equipped with two 4-inch electric blowers to supply the air needed for gasification and for combustion of gases. Results have shown that this gasifier unit consumes 25 to $30 \mathrm{~kg}$ of rice husks per hour. It can successfully oven-dry clay soil, which is the primary ingredient used for producing bleaching material. The gasifier for torrefying biomass, on the other hand, has 1.2-meter diameter reactor used 
to supply heat to a rotary torrefyer. This gasifier model is able to raise the temperature of the product to $250^{\circ} \mathrm{C}$ within 5 minutes. Results have further shown that it consumes $169 \mathrm{~kg}$ of rice husks per hour with $321.2 \mathrm{kWt}$ power output. Specific gasification rate is $150 \mathrm{~kg} / \mathrm{hr}-\mathrm{m}^{2}$ of the area of the reactor. The temperature of the burning gas ranges from $600^{\circ}$ to $800^{\circ} \mathrm{C}$. Recent developments have also shown that a 1.2-meter diameter reactor gasifier can successfully activate coal in a rotary kiln and can effectively dry clay in a rotary dryer.

\subsection{Steam Boiler}

The gasifier (Appendix 6) is used to co-fire the existing steam boiler with diesel. The boiler is a 35-hp triple-pass, fire-tube steam boiler with 10 to $35 \mathrm{lbs}$ per hour rated steam capacity. The gasifier has $80-\mathrm{cm}$ diameter reactor equipped with a 3 -inch electric blower. The gas generated is delivered to the boiler, which is 10 meters away, by means of a high-pressure blower. Before the use of the gasifier in co-firing, the boiler consumes 27 liters of diesel fuel per hour with 60 psi steam pressure. On the other hand, co-firing the boiler with the gasifier has significantly reduced its diesel consumption to 12 liters per hour with 40 psi steam pressure. Rice husk consumption of the gasifier is only 7 sacks per hour. Aside from the boiler operator, one person is needed to attend the operation of the gasifer.

\subsection{Water Pump}

In this application, the gasifier (Appendix 7) is used to provide power for water pumps and other stationary agricultural machines. The gas generated is conditioned (i.e., cleansed and filtered) first before it is used as fuel for an internal combustion engine. The stationary-model fixed-bed gasifier developed at PHILRICE consumes 9 kilos of rice husks for two hours operation. It drives a 6.5-hp gasoline engine with an average speed of 2,600 rpm. Using a 3-inch pump, 4.8 to $6.5 \mathrm{li} / \mathrm{sec}$ discharge rate is achieved from a 3.5 to 1 meter ground water table. The mobile gasifier unit, on the other hand, has a reactor capacity of 4-kg rice husk per load for 1.35-hr engine operation. At 2085 rpm engine speed, water is pumped from an open source at a rate of $7.5 \mathrm{lps}$ with 1.3-meter head. A 0.30-meter mobile gasifier unit, coupled to a 16-hp Briggs and Stratton engine, has been commissioned to DAP Beneficiaries in Tagbilaran, Bohol. This gasifier unit is intended to be used for micro milling aside from water pumping. A 0.30-meter moving-bed modular-type gasifier was recently developed under the CLSU-
CRHET Rice Husk Project using 13.5-hp gasoline engine coupled to a 3-inch diameter shallow-tube well pump. Results have shown that 511 to 621 liters of water can be pumped per minute at 2- to 2.5-meters head.

\subsection{Electric Generation}

In this application, the gasifier (Appendix 8) is intended for decentralized power generation to produce electricity for village lighting (i.e., for group of houses and/or street lighting), rice milling, and others. The gas generated is cleansed with water and then allowed to pass through the wet scrubbers and packed-bed filters before it is injected into the intake manifold of an engine that drives the generator. A reconditionedsurplus engine is used to drive an asynchronous generator. In the 20-kWe model designed and developed by GIFO Project under SUKI Trading Corporation, a 0.4-meter diameter reactor gasifier is used to drive either a surplus 3-cylinder Suzuki gasoline engine using a 10-kVA, 220-volt single-phase asynchronous generator or a Toyota $3 \mathrm{~K}$ gasoline engine with 20-kVA generator having an output of 14 $\mathrm{kW}$ at a speed of $1800 \mathrm{rpm}$. The gasifier consumes 19 $\mathrm{kg}$ of rice husks per hour with $15 \%$ parasitic load. Specific fuel consumption rate ranges from 1.35 to 1.9 $\mathrm{kg} / \mathrm{hr}-\mathrm{kWe}$. A 0.6-meter diameter reactor gasifier, coupled to a 20-kVA generator, consumes $42 \mathrm{~kg}$ of rice husks per hour, with $2.1 \mathrm{~kg} / \mathrm{hr}-\mathrm{kWe}$ specific fuel consumption rate. Based on recent development on electric generation conducted at the CLSU-CRHET Rice Husk Project, in collaboration with 6M's $\mathrm{Ag}$ Biosystem Engineering Enterprise and Consultancy Corporation, it was found out that a 0.25-meter diameter gasifier can produce gas enough to fuel a 13hp Kenbo gasoline engine coupled to a 3-kVA generator producing $2.9 \mathrm{kWe}$ power output. Rice husks consumption is at $6 \mathrm{~kg}$ per hour with $0.9 \mathrm{~kW}$ parasitic load, giving a $2 \mathrm{~kg} / \mathrm{hr}-\mathrm{kwe}$ specific fuel consumption. At PHILRICE, a 100-kWe rice husk gasifier plant was designed and developed for rice millers or for those who are adjacent to the source of fuel. The gasifier has a reactor diameter of 1.2 meter and consumes rice husks at around $150 \mathrm{~kg}$ per hour. An 8-cylinder surplus General Motor engine is used to drive the 100-kVA three-phase AC synchronous generator.

\section{ECONOMICS AND SOCIAL BENEFITS OF RICE HUSK GASIFIER}

Since the gasifier uses rice husk as fuel, it is expected that the cost of generating energy using This 
technology is cheaper than that of conventional method that uses crude oil as fuel. Because of this, rice husk become a traded commodity nowadays. It costs around PHP2.60 per kilo of rice husks from Nueva Ecija delivered to Metro Manila.

The investment cost for the rice husk gasifier varies from PHP2,000.00 to 2,500 per kilowatt for thermal application and from PHP20,000.00 to $30,000.00$ per kilowatt for power application, depending on the design and on the complexity of application. Cost for the land, buildings, and other business related investments are not included. Small gasifier units, such as domestic and cottage industry stoves, are available at PHP2,000 per $\mathrm{kWt}$; while, large industry gasifiers cost around PHP2,500.00 kWt. Small gasifier units for power generation (i.e., up to $10 \mathrm{kWe}$ ) cost around PHP20,000.00 per kWe while big ones cost PHP30,000.00 per kWe. The difference in cost can be attributed to the cost of added accessories.

Table 4 shows the operating cost of the gasifiers with investment cost of PHP2,500.00 per kWt for thermal application and PHP30,000 kWe for power generation. This operating cost analysis was done to determine the viability of investing in the technology. As shown, the fixed and variable costs for the gasifier used for thermal applications are PHP1.27 per kWt-day and PHP6.00 to 14.62 per kWt-day, respectively. For power generation, the fixed and variable costs are PHP10.68 per kWe-day and PHP18.60 to 43.67 per kWe-day, respectively. The cost to generate thermal power ranges from PHP0.91 to 1.99 per kWt-hr while the cost to generate electrical power ranges from PHP4.31 to 7.99 per kWe-hr. A saving of PHP26.87 to 45.68 per kWt-day can be derived from the use of the gasifier for thermal application over the use of conventional-fueled (i.e., kerosene, diesel, and LPG) devices. Comparing the cost of generating power using the gasifier with the current cost of electricity of PHP10.00 per kWe-hr, a saving of PHP32.06 to 123.09 per kWe-day can be derived when operating the gasifer for 8 to 16 hours a day. Payback period for thermal gasifier is between 1.9 to 4.7 months while for power gasifier is between 0.7 to 2.6 months.

The use of gasifier, basically, offers a lot of benefits not only to the users but also to the industry and to the government, in general. With the prevailing price of more than PHP40 (1 USD) per liter of fossil fuel, the equivalent cost of rice husk fuel is only PHP4.00 to 12.00. In terms of woodfuel, the equivalent cost is around PHP2.00 to 6.00 per kilogram. Given this scenario, electricity can be made available, especially in areas that are far from grid, cheaper by half of the present electric cost of PHP10.00 per kw-hr. Furthermore, aside from the saving derived on fuel, the gasifier technology provides income to manufacturing industry in terms of profit in its production, creates market opportunity to suppliers of raw materials as well as employment opportunity to the local people who are engaged in building it, and provides income for the Local Government Units in terms of tax revenue. Reduction in $\mathrm{CO}_{2}$ and black carbon emissions can be obtained when gasifier is used over direct-combustion devices. The by-product in operating the gasifier, which is the char, is used as source of carbonized rice husks to improve the fertility of the soil, to increase the water holding capacity of the soil, and to enhance bacterial decomposition in the soil. Burning the char further, the by-product is ash which is used as a supplementary supply of silica in cement industry, as ingredient in the production of locally-mixed refractory cement and in the production of cement fiber board. In Vietnam, it is used as an ingredient in making geopolymer, a construction material used for housing and small bridges.

Table 4: Operating Cost Analysis of the Gasifiers (As of May 2013)

\begin{tabular}{|c|c|c|}
\hline Parameters & Thermal & Power \\
\hline \hline Investment Cost & PHP2,500.00 per kWt & PHP10.68 per kWe-day \\
\hline Fixed Cost & PHP1.27 per kWt-day & PHP18.60 to 43.67 per kWe-day \\
\hline Variable Cost & PHP6.00 to 14.62 per kWt-day & PHP29.28 to 54.35 per kWe-day \\
\hline Total Cost & PHP7.27 to 15.89 per kWt-day & PHP4.31 to 7.99 per kWe-hr \\
\hline Power Generating Cost & PHP0.91 to 1.99 per kWt-hr & PHP32.06 to 123.09 per kWe-day \\
\hline Saving & PHP26.87 to 45.68 per kWt-day & 0.7 to 2.6 months \\
\hline Payback Period & 1.9 to 4.7 months & \\
\hline
\end{tabular}

USD1 = PHP40.00. 


\section{CONCLUDING REMARKS}

After almost half a decade of development endeavor on the downdraft rice husk gasifier particularly for industry use, the technology has now gone its way to adoption stage meeting the need of the various industries for a low-cost and clean source of energy. This may be due to the fact that the technology is timely in supplementing the supply of energy while, at the same time, mitigating the problem on global warming caused by the excessive greenhouse gas emission.

The technology is simple and can easily be scaledup or scaled-down, depending on the energy need and the intended application. It can be locally built using available materials and resources in the locality, creating a market for suppliers of materials, also creating an employment opportunity for the local people.

Because of the shortage in power coupled with the increasing demand for electricity, development of medium- to large-scale power generating plants must be prioritized, especially in off-grid areas. More effort must be done in the development of the gasifier for thermal applications to make it operate either on stand alone or on hybrid, i.e., in combination with available fuel, in order to meet the energy needed by the various industries.

\section{APPENDIX 1: THE GASIFIER FOR DOMESTIC AND SMALL COTTAGE INDUSTRY USES}

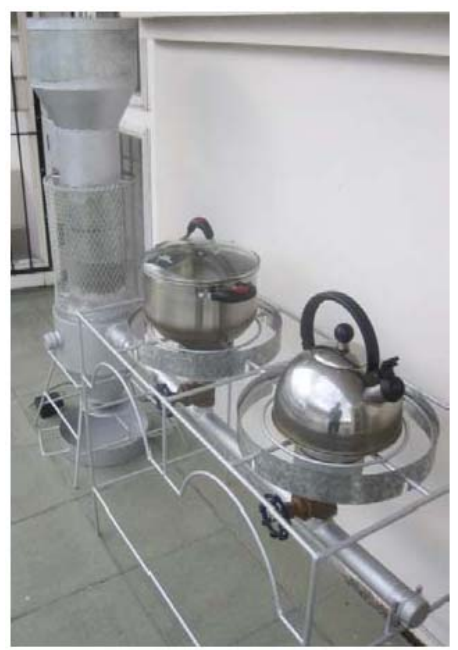

The 2-Burner Household-Size Gasifier Stove

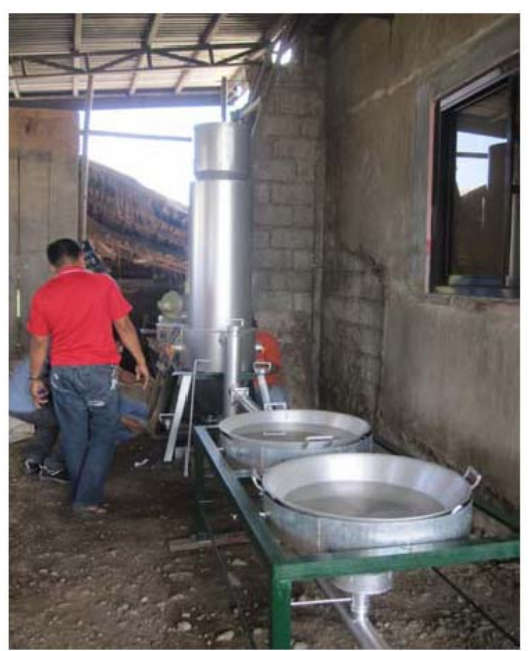

The 2-Burner Stove for CocoSugar Processing

\section{APPENDIX 2: THE GASIFIER FOR BAKERY OVEN}

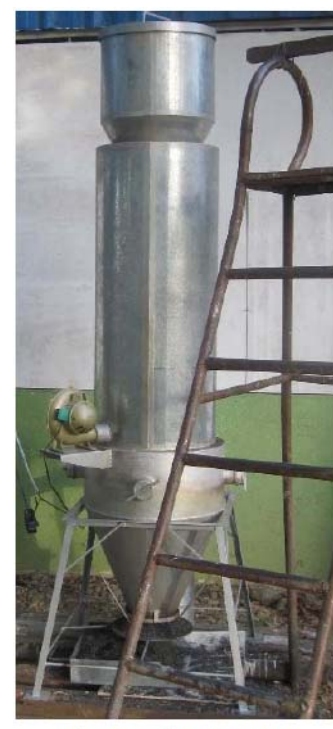

The Gasifier Reactor

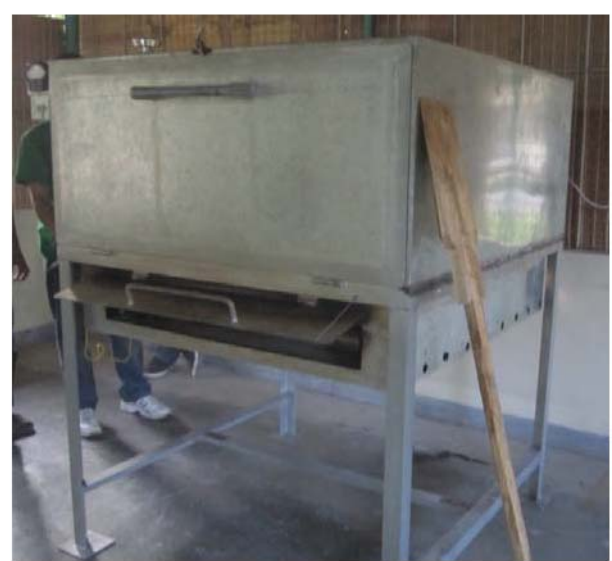

The Indirect-Heated Oven for Gasifier 


\section{APPENDIX 3: THE GASIFIER FOR PADDY DRYING APPLICATION}

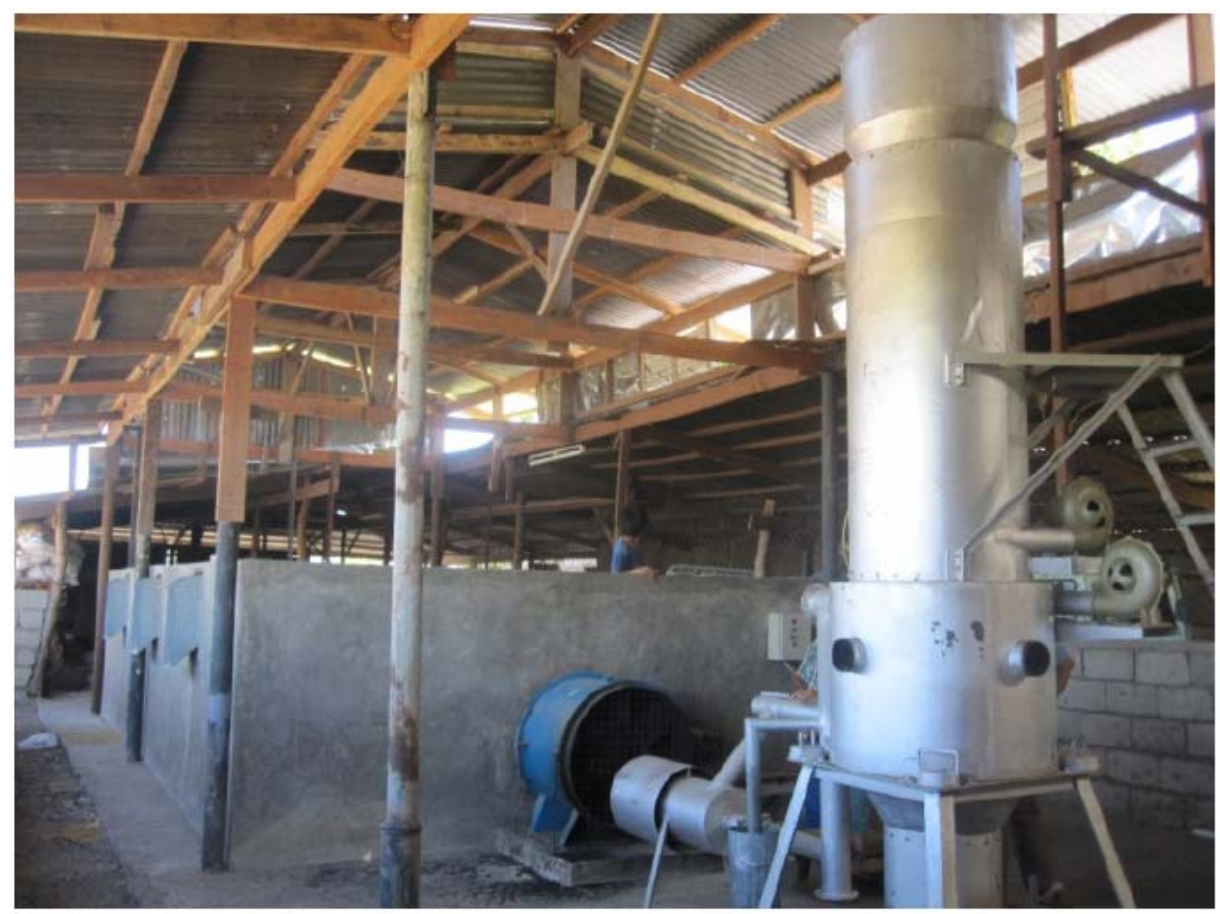

The 6-Ton Capacity Flatbed Paddy Dryer with Gasifier

APPENDIX 4: THE GASIFIER FOR ROTARY KILN FIRING

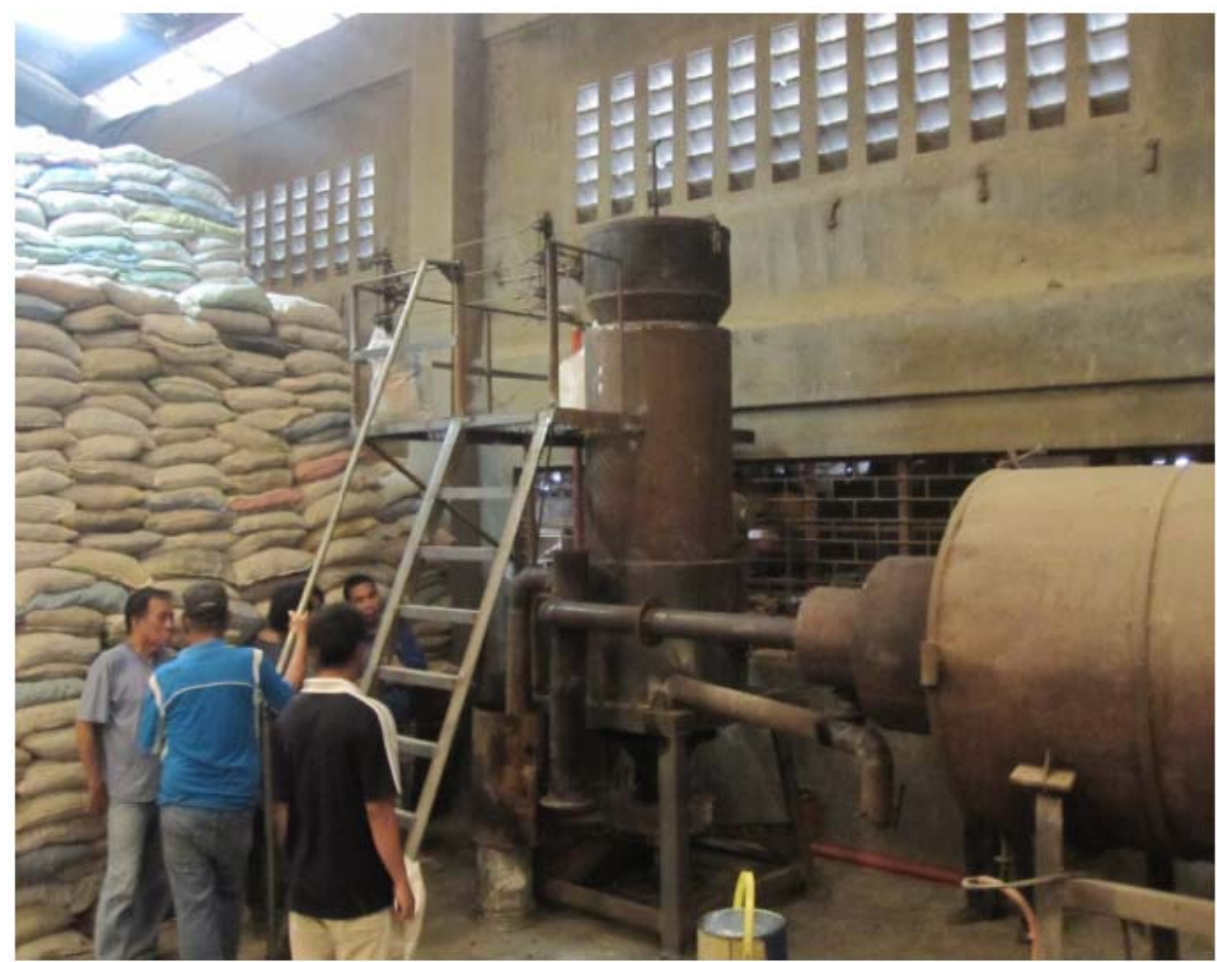

The Rotary Kiln Dryer for Drying Clay Soil 


\section{APPENDIX 5: THE GASIFIER FOR TORREFYING BIOMASS}

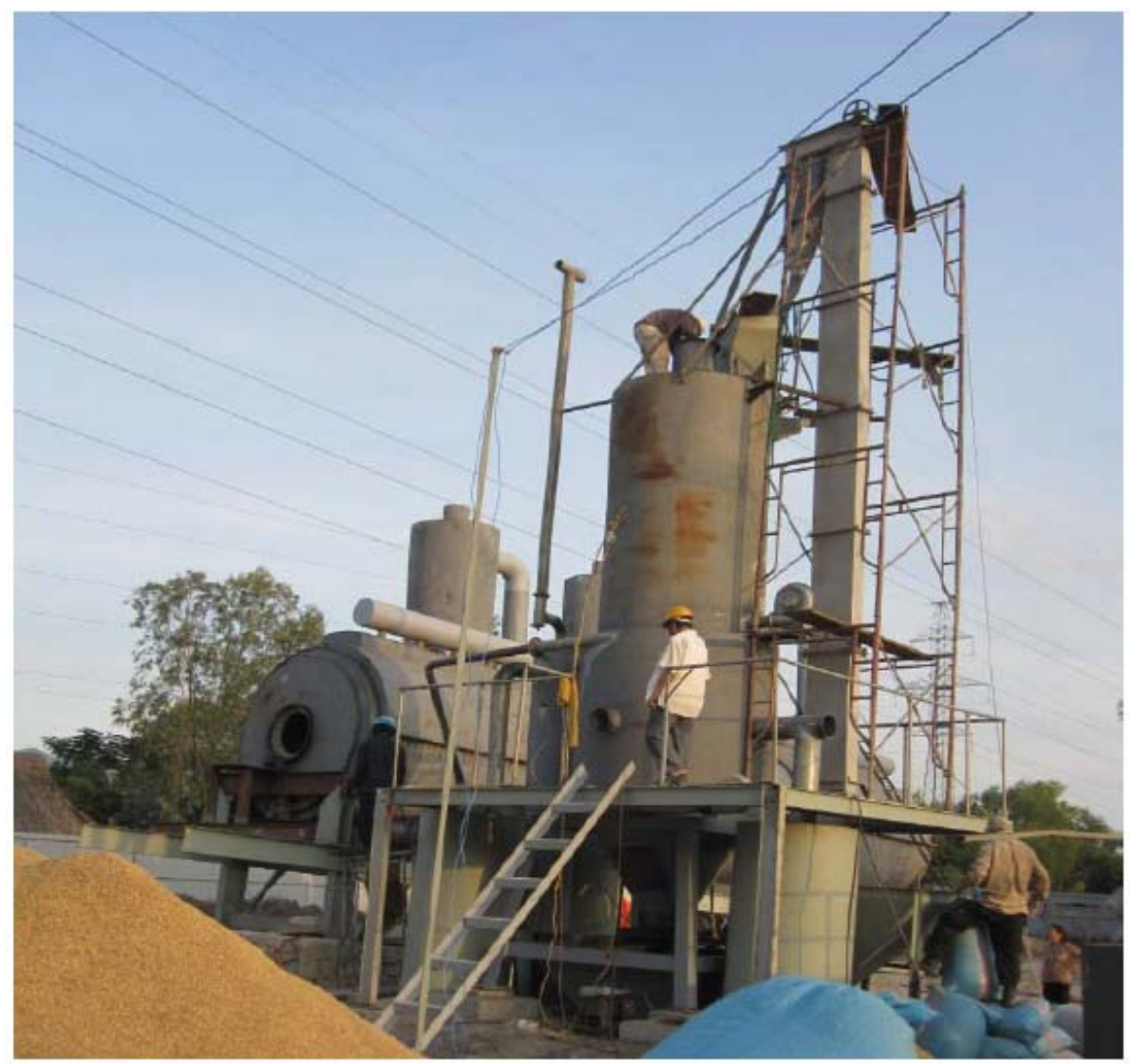

The 1.2-meter Gasifier with Rotary Type Torrefyer

\section{APPENDIX 6: THE GASIFIER FOR CO-FIRING STEAM BOILER}

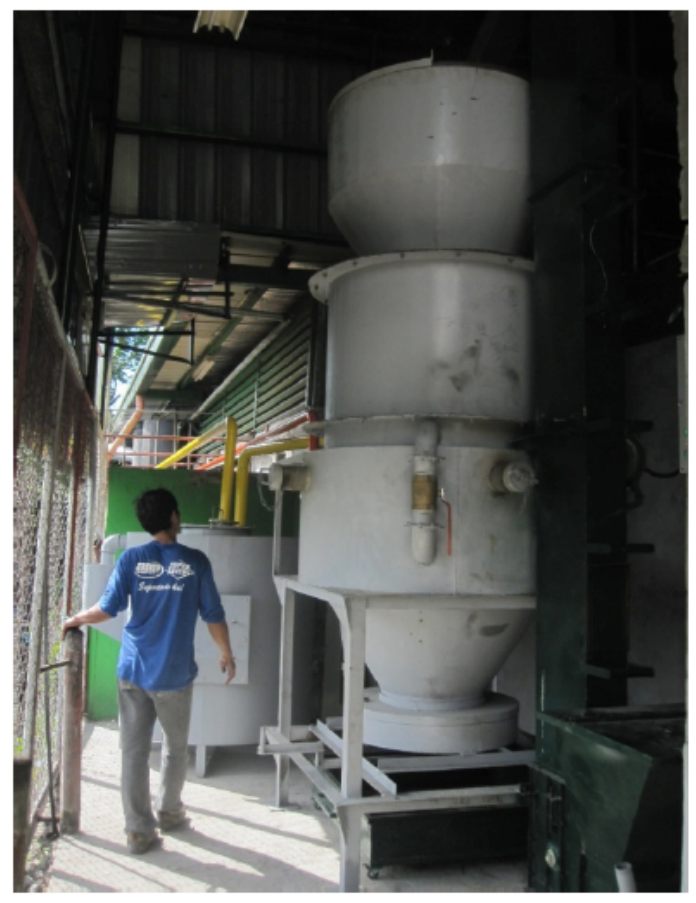

The 0.8-meter Gasifier

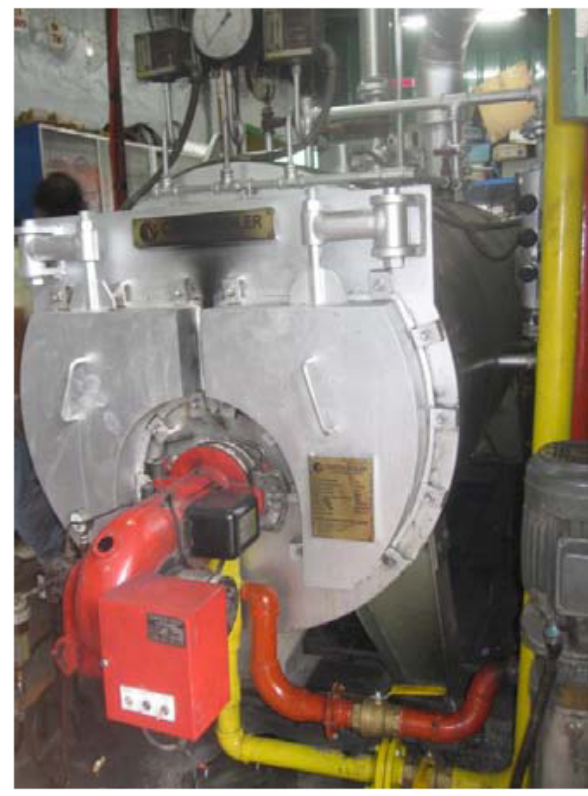

The 35-BHP Steam Boiler 


\section{APPENDIX 7: THE GASIFIER FOR WATER PUMPING}

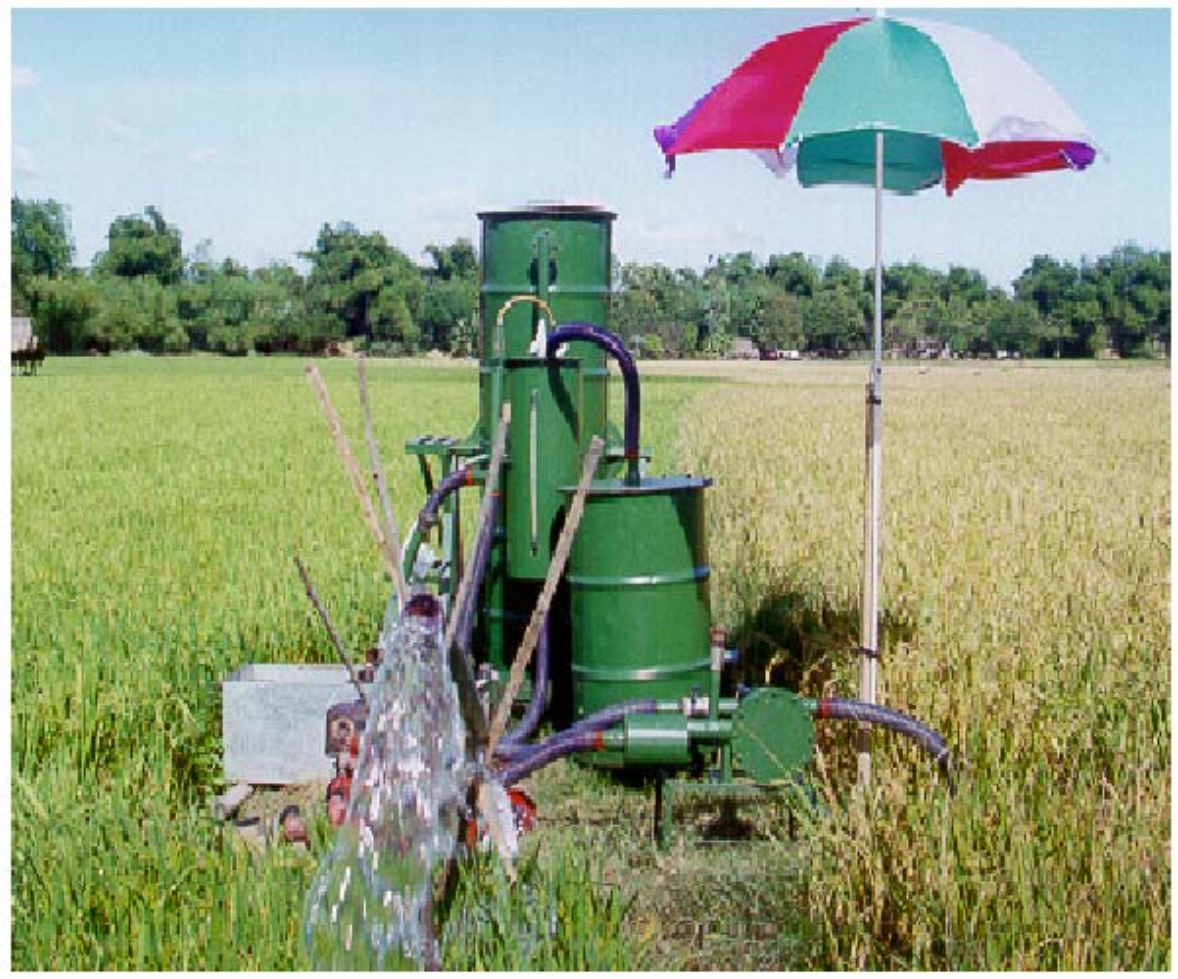

The Stationary Unit

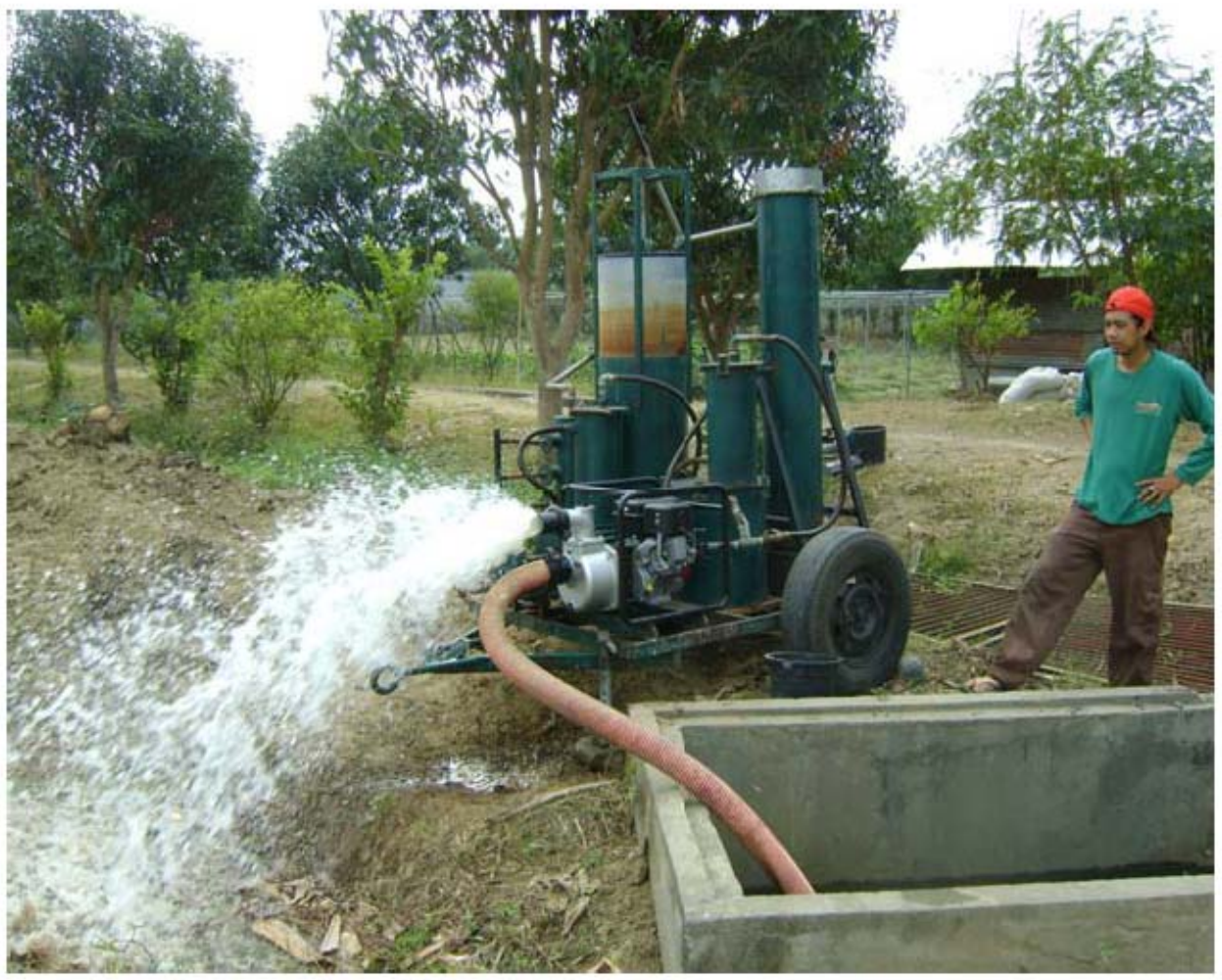

The Mobile Unit 


\section{APPENDIX 8: THE GASIFIER FOR ELECTRICAL POWER GENERATION}

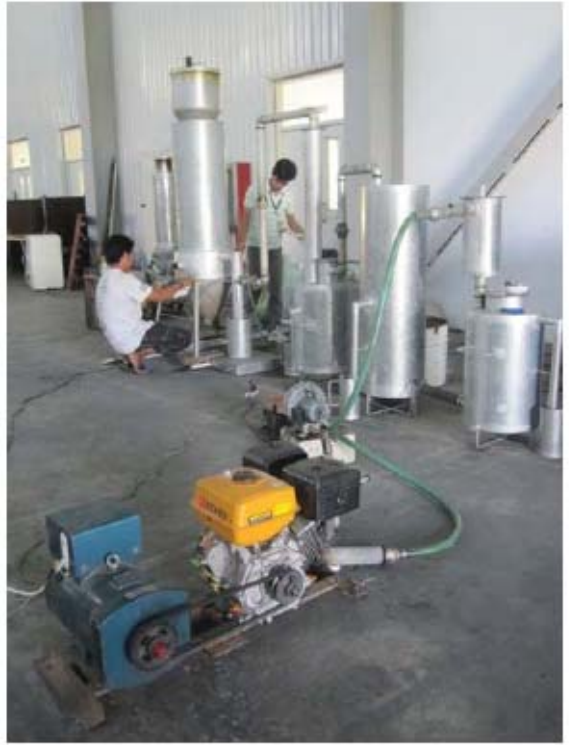

The 3-kWe Plant

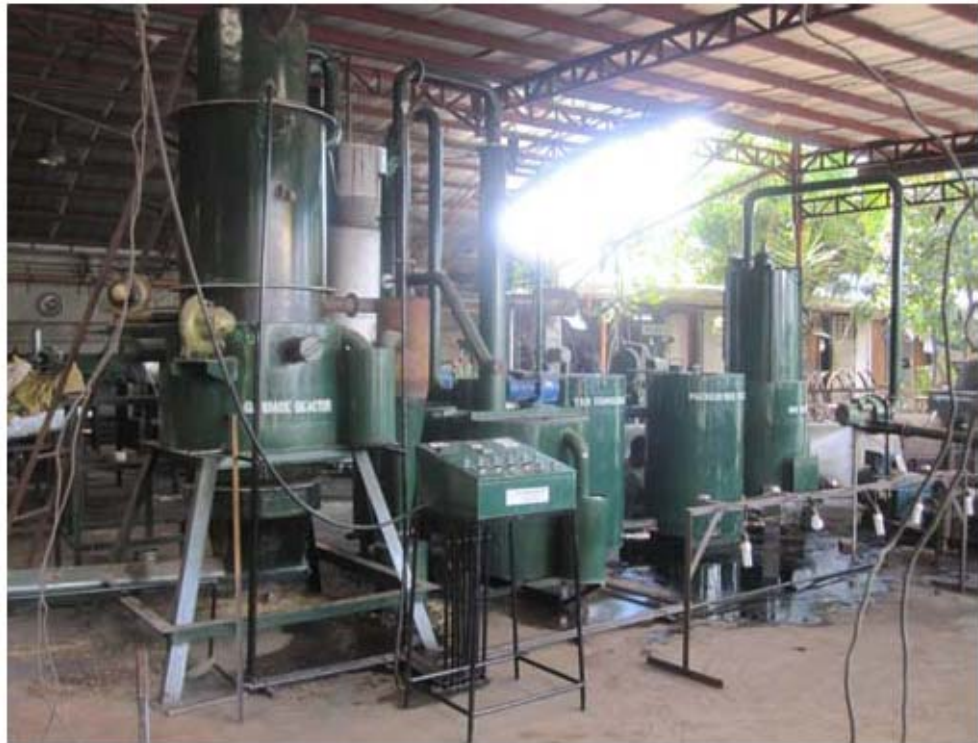

The 20-kWe Plant

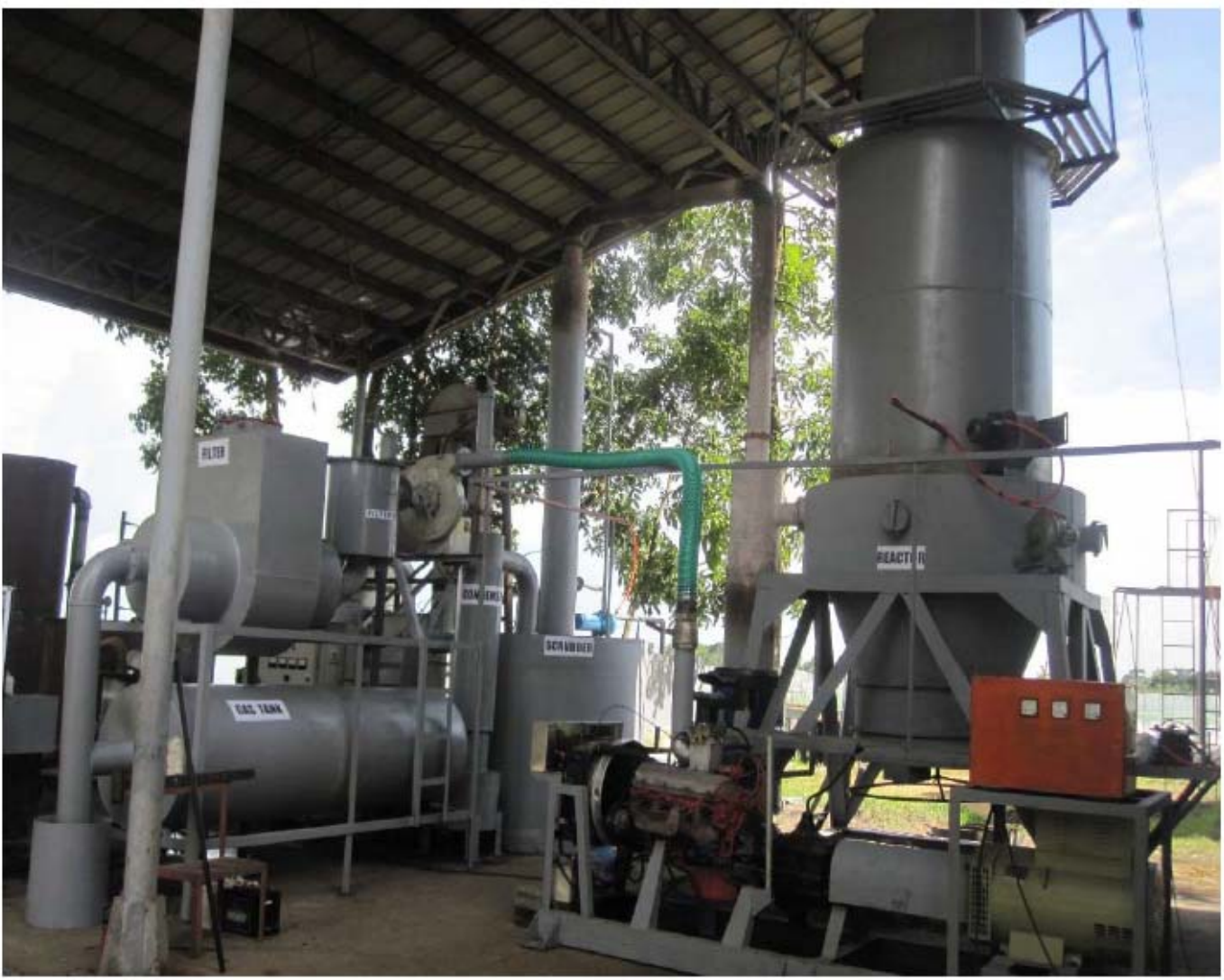

The 100-kWe Plant 


\section{REFERENCES}

[1] Belonio A. Rice Husk Gas Stove Handbook. Appropriate Technology Center, Central Philippine University 2005; p. 141. www.crest.org/discussiongroups/resources/stoves/ Belonio/Belonio_gasifier.pdf

[2] Belonio AT, Belonio DAH, Larano L. A Continuous-Flow Rice Husk Gasifier for Thermal Applications. Paper presented during the $10^{\text {th }}$ PCIERD Regional S\&T Fora and Competition held at FNRI Training Room, DOST Compound, Bicutan, Taguig, Metro Manila, Philippines 2010; p. 18. http://www. bioenergylists.org/files/Continuous-Flow_Rice_Husk_GasifierBelonio-2010_0.pdf

[3] Beagle EC. Rice Husk Conversion to Energy. Food Agricultural Service Bulletin. Food Agricultural Organization of the United Nation. Rome, Italy 1978; p. 155.

[4] Belonio AT, Sicat EV, Cuaresma FD. Design and Development of a Moving-Bed Downdraft Rice Husk Gasifier for Thermal and Power Applications. Proceedings of the ERDT $7^{\text {th }}$ Conference: Sustainability through ERDT: Towards a Carbon-Neutral Economy. Manila Hotel, Manila. September 16, 2011; pp. 17-22.

[5] Belonio A, Atmowidjojo D, Minang B. Biomass Gasification: Basics and MJA Experiences on Thermal Application. Paper presented during the seminar on Solar Cell and Biomass Gasifier Stove held at PT Widya Dharma Artha, Graha Pool, Jl. Merdika No. 110 Ciwaringin, Bogor, Indonesia 2009; p. 25.
[6] Belonio AT, Ramos JA, Regalado MJC. Rice Husk Gasifier: Thermal and Power. Lecture Handout at DAP Training on Rice Husk Gasifier Engine System, Tagbilaran City, Bohol on December 7, 2011; p. 46.

[7] Belonio AT, Ocon VB. Rice Husk Gasifier: A Technology for Generating Heat and Power. Paper presented during the Symposium on Peso from Waste ++ (Mitigating Measures for Climate Change) held at the Legislative Building, Provincial Capitol, Matti, Digos City on February 10, 2012; p. 29.

[8] Juliano AS, Ramos JA, Molinawe LB. Rice Husk Power Gasifier Engine-System. Presented during the $21^{\text {st }}$ National Rice R\&D Conference, PhilRice, Science City of Munoz, Nueva Ecija, Philippines, 11-13 March 2008.

[9] Juliano AS, Ramos JA, Molinawe LB, Villota RE, Bautista EU. Development of a Mobile Ricehull Gasifier Engine-Pump System. Presented during the $24^{\text {th }}$ National Rice R \& D Program conducted at PhilRice Maligaya, Science City of Munoz, Nueva Ecija on March 16-18, 2011.

[10] Kaupp A. Gasification of Rice Hull: Theory and Praxix. Federal Republic of Germany: GATE/GTZ. 1984; p. 303. http://dx.doi.org/10.1007/978-3-322-96308-6

[11] Kaupp A, Goss JR. Small Scale Gas Producer Engine Systems. GATE/GTZ. Frieds. Vieweg \& Sohn Verlagsgesellshaft $\mathrm{mbH}$ Braunschewerig. Federal Republic of Germany 1984; p. 278. 